\title{
Evaluation of organic matter, bio-inoculants and inorganic fertilizers on growth and yield attributes of tomato with respect to the management of plant-parasitic nematodes
}

\author{
Sartaj A. Tiyagi*, Safiuddin, Rose Rizvi, Irshad Mahmood, Zehra Khan \\ Plant Pathology and Nematology Laboratory, Department of Botany, Aligarh Muslim University, Aligarh 202002, India
}

\section{A B S TR A C T}

\begin{abstract}
A field experiment was conducted to assess the effect of inoculations of biological nitrogen fixers using Azotobacter and Azospirillum individually and concomitantly with different recommended doses of inorganic nitrogen fertilizers and organic matter in the form of sesame (Sesame indicum) cake on the growth, yield and quality traits of tomato (Solanum lycopersicon L.) in relation to the management of plant-parasitic nematodes. The multiplication rate, egg masses, and root-galls per plant of these nematodes were reduced significantly by the individual inoculation of biological nitrogen fixers as well as with organic matter; while concomitant inoculation of bio-inoculants showed a synergistic effect in increasing crop growth and yield. Azospirillum was found to be more effective than Azotobacter. The highest improvement was recorded in the yield and growth parameters, plant height, fresh and dry weights, percent pollen fertility, green fruits yield per plant, chlorophyll content and ascorbic acid content when these biological nitrogen fixers were added concomitantly in various combinations. The Nitrogen-Phosphorus-Potassium (NPK) contents in plants and in soil increased considerably in almost all the combinations whenever these bio-fertilizers were inoculated and thus, reduce the fertilizers needed for commercial tomato production. The best results were obtained with $100 \%$ recommended dose of nitrogenous fertilizers along with the bio-fertilizers and farm yard manure.
\end{abstract}

Keywords: Azotobacter; Azospirillum; Sesame cake; Tomato, Management; Plant-parasitic nematodes

\section{INTRODUCTION}

Tomato (Solanum lycopersicon L.) is one of the major crops grown widely and processed in almost every country in the world. They have high degree of lycopene and ascorbic acid content (Kaur and Kapoor, 2008). Tomato and its products are used as preventive strategies against some diseases such as cancer and cardio vascular diseases (Cavene Adam et al., 2005). Tomato is universally considered as 'Protective Food'. It is a rich source of minerals, vitamins, and organic acids. The estimated world production of tomato is about 125 million tons and the total area under its cultivation is about 45.5 lakh ha. Indian contribution to the annual world production was 10.26 million tones with an area of 5.72 lakh in 2006 (Mane et al., 2010). The production in India falls short of expectation as compared to other countries which may be partly due to weather fluctuations and partly due to diseases caused by various plant pathogens. Plantparasitic nematodes are serious threat to crop production, causing an estimated US $\$ 125$ billion loss/year worldwide (Chitwood, 2003). Among the parasitic nematodes, rootknot nematodes cause yield losses in tomatoes of up to $46 \%$ in India (Bhatti and Jain, 1977; Reddy, 1985). On the other hand, plant nutrients supply is an important and promising component for sustainable production of tomato crop and to restore soil fertility. Nutrient management based on eco-friendly principles of balanced fertilization not only enhances the fertilizer use efficiency but also help to sustain the productivity. Therefore, it is a matter of concern to overcome nutritional effects and simultaneously management of the nematodes with the help of intensification of agriculture with the use of chemical fertilizers, broad spectrum pesticides,

\footnotetext{
*Corresponding author:

Sartaj A. Tiyagi, Plant Pathology and Nematology Laboratory, Department of Botany, Aligarh Muslim University, Aligarh 202002, India. E-mail: sartaj_a2000@yahoo.co.in
} 
etc. It has been accepted that continuous application of chemical fertilizers and plant protection chemicals with the advent of green revolution in the early sixties, though increased productivity but had adverse effects on the beneficial microbial population. It shows direct toxicity to predators, fish and man (Munakata, 1977; Pimentel, 1981). Yadav and Kumar (2009) observed deleterious impact due to pesticides application on soil health and environment. These fertilizers and chemicals are also costly, and does not support optimal microbial activities and is unaffordable to many small scale farmers. This has increased urgency in the search for alternative and eco-friendly methods to regulate plant pathogens as well as nutritional requirements of the plants. Organic sources of nutrients like organic matters, compost and crop residues are widely used in vegetable crops in India and elsewhere. Integrated plant nutrient management is an important component for sustainable agriculture. The best available options lie in the complementary use of bio-fertilizers and organic matter in suitable combinations with chemical fertilizers. Microbial inoculants or biofertilizers are important components of organic farming. These bio-fertilizers have shown encouraging results in sustaining the crop productivity and improving the soil fertility (Govindan and Thirumurugan, 2005). Organic manures on the other side, provide a good substrate for the growth of micro- organisms and maintain a favorable nutrient supply, environment and improve soil physical properties. Biological nitrogen fixers are known to exert indirect effects on soil microbiological activities which in turn help the plant to grow better (Singh and Singh, 2006), besides direct effects on nitrogen fixation and phosphorus mobilization (Rana and Chandel, 2003). They also produced hormones, vitamins and other growth factors for plant growth and development, besides suppression of the growth of phytopathogens (Widham et al., 1989; Devidas and Rehberger, 1992; Verma et al., 2000). The bio-fertilizers like Azospirillum and Azotobacter associated with the rhizosphere of many crop plants, harvest atmospheric nitrogen, which in due course is made available to the plants or released in soil thus increasing soil fertility. These biofertilizers are an ecologically sound, economically viable and a partially substitute to hazardous nitrogenous chemical fertilizers. Although the effects of bio-inoculants in legumes, cereals and oil-seed crops have been well established, however, no much informations are available on vegetables like tomato. Keeping in view the nutritional requirements of tomato and association of the plant- parasitic nematodes with the roots of this plant, the present investigation was undertaken to study the effect of inoculations with biological nitrogen fixers using Azospirillum and Azotobacter on growth, yield and quality parameters of tomato (Solanum lycopersicon L.) cv. 'Pusa Ruby' under different levels of nitrogenous fertilizers and sesame cake (Sesame indicum) in relation to the multiplication of plant-parasitic nematodes.

\section{MATERIAL AND METHODS}

A field experiment was established at the University Agricultural Research Farm of Aligarh Muslim University during two winter seasons (2007-2009) to determine the effect of inoculation of bio-inoculants using Azotobacter chroococcum and Azospirillum brasilense singly or in various combinations along with sesame (Sesame indicum) seed cake and recommended doses of inorganic nitrogenous fertilizer on growth, yield and quality traits of tomato (Solanum lycopersicon L.) cultivar 'Pusa Ruby'. The field was protected with barbed wire and thoroughly ploughed. The small beds of $6 \mathrm{~m}^{2}$ were prepared leaving $0.5 \mathrm{~m}$ buffer zone between them. The field was infested with the population of plant-parasitic nematodes.

The soil was sandy loam in texture, having $\mathrm{pH}$ of 6.3 and 6.7 , organic carbon 1.07 and $1.12 \%$ and available $\mathrm{N}, \mathrm{P}$ and $\mathrm{K}$ of 135.30 and $182.52,41.53$ and 44.29 and 57.31 and $69.25 \mathrm{~kg} / \mathrm{ha}$, respectively for the respective years. The treatments consisted of $100 \%$ $\mathrm{RDN}+$ Azotobacter $+\mathrm{SC}$ (T1), 75\%RDN+Azotobacter+SC (T2), $50 \%$ RDN + Azotobacter $+\mathrm{SC}$ (3), $100 \%$ $\mathrm{RDN}+$ Arospirillum +SC (T4), 75\% RDN+Azospirillum +SC (T5), $50 \%$ RDN + Arospirillum $+\mathrm{SC}$ (T6), $100 \%$ $\mathrm{RDN}+$ Arotobacter+Azospirillum $+\mathrm{SC}$ (T7), 75\%RDN + Azotobacter + Azospirillum $+\mathrm{SC}$ (T8), 50\%RDN $+A z$. otobacter+Azospirillum +SC(T9), Azotobacter+SC(T10), Azospirillum +SC(T11), Azotobacter+Azospirillum +SC (T12), Azotobacter alone (T13), Azospirillum alone (T14), SC alone(T15), 100\% recommended dose of N,P,K (T16) and untreated control (T17) were laid out in a random block design with 5 replications. Treatment number (T18) was for initial nematode population. Each bed received 15 tons/ha farmyard manures at leastone month for better decomposition prior to the planting.

For preparation of bio-inoculants, pure culture of Azotobacter chroococcum and Azospirillum brasilense isolated from the roots and rhizosphere soil of tomato, these were identified and screened on the basis of certain biochemical tests such as gram reaction. These cultures were grown on Jenson's and $\mathrm{N}$ - free malate respectively for four days. The cells were centrifuged, washed twice in sterile distilled water and suspended in $0.15 \%$ phosphate buffer at $\mathrm{pH} 7.0$. Seed treatment with Azotobacter and Azospirillum each @25g/ $\mathrm{kg}$ seed for 20min. and then seedling root-dip @2\% for $30 \mathrm{~min}$. At transplanting stage according to the procedure of Kavitha et al. (2003) as single and in combined 
inoculations which were tested with different levels of nitrogen i.e. $0,50,75$ and $100 \%$ of the recommended doses. Two additional treatments were given including the full recommended doses of $\mathrm{N} @ 80 \mathrm{~kg} / \mathrm{ha}$. According to the inoculation schedule, the beds were separately treated with sesame cake@110 kg/N ha and immediately watered to assist in the decomposition of cake. The planting of tomato seedlings at three-weeks old was done at spacing $75 \mathrm{~cm} / 45$ in $3 \times 2-70 \mathrm{~m}$ beds. Nitrogen was applied in the form of urea depending upon the treatments in split doses half as basal and another half was applied in two equal splits at 3 and 6 weeks after transplanting. Phosphate and potash each@60 kg/ha were applied in the form of single superphosphate as basal and murate of potash in two equal splits, one as basal and rest at 6 weeks after transplanting to all the beds. Necessary watering and weeding were done as and when required.

The experiment was terminated after 100 days of inoculations of bio-inoculants. Measurements of growth, yield and quality parameters were recorded during both years of investigation. Mature tomatoes were harvested in 5 picking at 20 days interval to get the yield. The ascorbic acid content from tomato fruit tissues was determined using 2, 6 dichlorophenol indophenols dye (AOAC, 1980).

At the flowering stage, the pollen fertility (percentage) was estimated by the method of Brown (1949) using stainability of pollen grains in 1\% acetocarmine solution. The pollen grains which were regular in shape and stained was considered as fertile and those irregular and unstained as sterile. Chlorophyll content of leaves was estimated by the method of Hiscox and Israelstam (1979). One hundred milligram of leaf pieces were placed in a vial containing dimethyl sulfoxide (DMSO) and the extract of chlorophyll was dissolved into the fluid by incubating for $60 \mathrm{~min}$. The extract was transferred to a graduated tube and made upto $10 \mathrm{ml}$ with DMSO and assayed immediately. A sample of $3 \mathrm{ml}$ chlorophyll extract was transferred to a cuvette and the optical density (O.D) value at 645 and $663 \mathrm{~nm}$ were read in Spectronic-1001 Spectrophotometer against a DMSO blank.

\section{Extraction of nematode population}

The population of plant-parasitic nematodes was determined from each bed before treatment as well as after terminating the experiment by processing representative soil- samples of Cobb's sieving and decanting method along with Bearmann's funnel technique (Southey, 1986). The number of nematodes were identified and counted. The number of each nematode species was determined from five counts. Numbers of egg masses as well as rootgalls caused by root-knot nematode, Meloidogyne incognita per plant were also counted.

\section{Estimation of N, P, K in plants and soil}

Nitrogen content in plants and residual soil were determined according to the procedure given by IITA (1975). The phosphate and potash contents from plant were estimated by the method of Lindner (1944). Similarly, phosphate and potash contents in plants and residual soil were determined with the method of Olsen et al., (1954) and Jackson (1973), respectively. The data of two years have been pooled and analysed statistically according to Pansey and Sukhatme (1978).

\section{RESULTS AND DISCUSSION}

\section{Plant growth traits}

The results presented in Table 1 clearly indicated that the inoculation of these bio-inoculants individually or incombination improved the growth, yield and quality traits of tomato in the presence of different levels of inorganic nitrogen and sesame cake. The present investigations revealed that plant height, fresh as well as dry weights and percent pollen fertility were greatly enhanced by all treatments. The treatments of dual inoculation of biofertilizers like Azotobacter and Azospirillum along with $100 \%$ recommended dose of nitrogen recorded highest plant height $(81.63 \mathrm{~cm})$, fresh weight $(180.47 \mathrm{~g})$, dry weight $(62.58 \mathrm{~g})$ and pollen fertility (98.64\%) as compared to untreated control where plant height $(37.42 \mathrm{~cm})$, fresh weight $(77.33 \mathrm{~g})$, dry weight $(26.65 \mathrm{~g})$ and pollen fertility $(69.29 \%)$ were determined. Similar observations have also been reported by Sen Gupta et al. (2002) in growth parameters of tomato due to concomitant inoculation of both the biological-nitrogen fixers. Behl et al. (2007) and Sala et al. (2007) reported significant improvement in crop production with inoculation of nitrogen fixing bacteria, phosphate solubilizing bacteria, and AM fungi. Inoculation of crop with beneficial microorganisms can enhance the atmospheric nitrogen fixation, decompose organic wastes and residues, improve soil properties, enhance nutrient cycling and produce bioactive compounds such as vitamins, hormons and enzymes which stimulated plant growth (Wu et al. 2005). Several workers (Bahadur et al., 2009; Upadhyay et al. 2012) also observed that the combined inoculation of organic manures and biofertilizers increased yield and improved the nutritional value of vegetables.

The number of green fruit yield per plant significantly increased in all the treatments. The combined inoculation of Azotobacter and Azospirillum with 100\% recommended dose of nitrogen resulted in maximum green fruit per plant. This parameter was found to be highest as compared to the sole application of inorganic nitrogen $(100 \%$ recommended dose) and sesame cake. Soil application of Azospirillum along with sesame cake and $100 \%$ recommended dose of 
Tiyagi, et al.: Organic management of phytonematodes

Table 1: Effect of sesame cake, bio-inoculants and $\mathrm{N}$-fertilization on growth and yield attributes of tomato (Solanum lycopersicon L.) in field condition*

\begin{tabular}{|c|c|c|c|c|c|c|c|c|c|c|}
\hline S. No. & Treatments & $\begin{array}{l}\text { Plant } \\
\text { height } \\
(\mathrm{cm})\end{array}$ & $\begin{array}{c}\text { Plant } \\
\text { fresh } \\
\text { weight } \\
\text { (g) }\end{array}$ & $\begin{array}{l}\text { Plant } \\
\text { dry } \\
\text { weight } \\
\text { (g) }\end{array}$ & $\begin{array}{c}\text { Pollen } \\
\text { fertility } \\
(\%)\end{array}$ & $\begin{array}{l}\text { Green } \\
\text { fruit } \\
\text { yield/ } \\
\text { plant } \\
\end{array}$ & $\begin{array}{c}\text { Chlorophyll } \\
\text { content } \\
(\mathrm{mg} / \mathrm{g})\end{array}$ & $\begin{array}{l}\text { Ascorbic } \\
\text { acid } \\
\text { content } \\
(\mathrm{mg} / 100 \mathrm{~g})\end{array}$ & $\begin{array}{c}\text { No. of } \\
\text { egg } \\
\text { masses/ } \\
\text { plant }\end{array}$ & $\begin{array}{l}\text { No. of } \\
\text { root } \\
\text { galls/ } \\
\text { plant } \\
\end{array}$ \\
\hline $\mathrm{T} 1$ & $100 \%$ recommended $\mathrm{N}+$ Azotobacter + sesame cake & 71.28 & 147.61 & 47.20 & 90.50 & 314.45 & 3.792 & 87.29 & 80.27 & 45.74 \\
\hline T2 & $75 \%$ recommended $\mathrm{N}+$ Azotobacter + sesame cake & 69.32 & 143.22 & 46.13 & 87.32 & 307.60 & 3.680 & 85.15 & 88.64 & 53.61 \\
\hline T3 & $50 \%$ recommended $\mathrm{N}+$ Azotobacter + sesame cake & 67.45 & 139.50 & 45.70 & 86.14 & 296.28 & 3.576 & 82.57 & 94.20 & 59.25 \\
\hline T4 & $100 \%$ recommended $\mathrm{N}+$ Azospirillum + sesame cake & 77.58 & 163.25 & 52.42 & 95.35 & 360.50 & 4.064 & 94.43 & 70.26 & 28.64 \\
\hline T5 & $75 \%$ recommended $\mathrm{N}+$ Azospirillum + sesame cake & 75.60 & 157.80 & 50.33 & 94.23 & 342.63 & 3.965 & 92.20 & 75.06 & 34.44 \\
\hline T6 & $50 \%$ recommended $\mathrm{N}+$ Azospirillum + sesame cake & 73.49 & 152.92 & 48.22 & 92.50 & 320.47 & 3.877 & 89.66 & 77.37 & 40.30 \\
\hline $\mathrm{T7}$ & $\begin{array}{l}100 \% \text { recommended } N+\text { Azotobacter }+ \text { Azospirillum + } \\
\text { sesame cake }\end{array}$ & 81.63 & 180.47 & 62.58 & 98.64 & 425.94 & 4.378 & 102.45 & 45.29 & 10.28 \\
\hline T8 & $\begin{array}{l}75 \% \text { recommended } N+\text { Azotobacter }+ \text { Azospirillum + } \\
\text { sesame cake }\end{array}$ & 79.77 & 173.33 & 57.07 & 96.25 & 394.50 & 4.225 & 97.03 & 54.52 & 18.47 \\
\hline T9 & $\begin{array}{l}50 \% \text { recommended } \mathrm{N}+\text { Azotobacter }+ \text { Azospirillum }+ \\
\text { sesame cake }\end{array}$ & 78.54 & 167.09 & 54.10 & 95.97 & 375.40 & 4.136 & 95.96 & 66.84 & 24.75 \\
\hline T10 & Azotobacter + sesame cake & 58.20 & 127.17 & 42.27 & 80.17 & 273.82 & 3.224 & 77.19 & 110.49 & 72.24 \\
\hline T11 & Azospirillum + sesame cake & 62.27 & 130.35 & 42.81 & 83.20 & 286.77 & 3.373 & 79.64 & 107.28 & 67.09 \\
\hline T12 & Azotobacter + Azospirillum + sesame cake & 65.19 & 135.60 & 45.50 & 85.12 & 290.31 & 3.490 & 82.00 & 100.01 & 65.16 \\
\hline T13 & Azotobacter alone & 52.30 & 117.47 & 39.19 & 75.66 & 262.56 & 2.935 & 72.29 & 137.50 & 87.70 \\
\hline T14 & Azospirillum alone & 55.66 & 122.50 & 41.23 & 79.30 & 272.44 & 3.074 & 75.30 & 122.36 & 78.15 \\
\hline T15 & sesame cake alone & 49.28 & 112.25 & 37.82 & 73.07 & 249.22 & 2.761 & 67.84 & 160.25 & 94.66 \\
\hline T16 & $100 \%$ recommended NPK & 45.59 & 103.94 & 34.20 & 71.62 & 223.50 & 2.592 & 64.73 & 246.00 & 101.93 \\
\hline \multirow[t]{2}{*}{ T17 } & Untreated control & 37.42 & 77.33 & 26.65 & 69.29 & 180.64 & 2.353 & 55.40 & 273.97 & 116.41 \\
\hline & $\begin{array}{l}\text { C.D. }(P=0.05) \\
\text { C.D. }(P=0.01)\end{array}$ & $\begin{array}{l}5.64 \\
7.50\end{array}$ & $\begin{array}{l}10.78 \\
14.34\end{array}$ & $\begin{array}{l}3.79 \\
5.04\end{array}$ & $\begin{array}{l}6.85 \\
9.11\end{array}$ & $\begin{array}{l}13.61 \\
18.10\end{array}$ & $\begin{array}{l}0.243 \\
0.323\end{array}$ & $\begin{array}{l}6.73 \\
8.95\end{array}$ & $\begin{array}{c}7.92 \\
10.53\end{array}$ & $\begin{array}{l}4.66 \\
6.20\end{array}$ \\
\hline
\end{tabular}

*Each value is a mean of five replicates

nitrogen produced more yield than that of Azotobacter application. Comparatively lesser green fruits yield per plant as well as other growth parameters were recorded from the beds treated with single and combined inoculations of Azotobacter and Azospirillum in the absence of 100\% recommended dose of inorganic nitrogen. Combined application of both the nitrogen fixers always showed better results when compared to single inoculation. This may be due to their synergistic effect. The enhancement in plant growth and biomass production might be due to increased rate of photosynthesis and higher metabolic activities, mobilization of some movable forms of important nutrients, production of growth promoting substances like gibberellic acid, indole acetic acid and dihydrozeatin (Aguilar-piedras et al., 2008) which have positive influence on the physiological activity of the plants resulted in enhanced fruit production and diameter, ultimately increased the average fruit weight and subsequently inhibited the soil borne pathogens by biofertilizers. Our findings are in agreement with those of (Wange and Kale, 2003; Chaitra and Patil, 2007; Jain et al., 2007) in several other crops. The combined effect of inorganic, organic and biofertilizers proved to be better and this may be due to joint action which led to enhanced vegetative growth and influenced physicochemical properties that imparts favorable soil structure for root growth (Sarkar et al., 2003; Pernes-Debuyser and Tessier, 2004), and enhancing mineral uptake by the roots (Okon and Itzigsohn, 1995). Since the application of organic matter and inorganic fertilizers improved the root growth. It could have resulted in better extraction of water from the soil profile. Organic fertilizers influenced both yield and plant micronutrient contents. Thus it helped to sustain crop productivity as has also been studied by Mottaghian et al. (2008). Yang et al. (2004) observed that the root length density increased by $40 \%$ with the application of organic manure, and they also noticed that incorporation of organic manures significantly increased N, P and K uptake by the plants and hence increased crop productivity. It is stressed upon here that the application of inorganic fertilizers not only provides the required nutrients to the plants but also improve the root biomass and its penetration thereby helping in water and better nutrient uptake.

Rajaee et al. (2007) also reported that free-living nitrogen fixing microorganisms like Azotobacter and Azospirillum increase root development, water content and mineral uptake, and produce plant hormones which might be responsible for enhancement of growth parameters of tomato plants. Similarly, Malik et al. (2005) observed significant improvement in grain yield, chlorophyll content and delayed flowering due to application of Azotobacter culture. However, inoculations of Azospirillum promoted lateral roots and enhance root length (Govindan et al., 
2009). The total bacteria and nitrogen fixers were also found higher in all the treatments which received the inoculum of Azospirillum.

The chlorophyll content and ascorbic acid content increased significantly in all the treatments. Application of organic matter like sesame cake in tomato might have increased the activities of beneficial micro-organisms due to increased organic pool in soil, which resulted in production of growthpromoting substances and improved nutrient availability for longer period throughout the crop growth, and thus the use of organic sources and the beneficial effects on the growth of some other crops (Knox et al., 2011; Tiyagi et al., 2010). The use of biofertilizers also influenced the metabolic activities of plants, thus increasing the chlorophyll content and ascorbic acid content. The combined effect of inorganic, organic and biofertilizers proved to be better than the individual one. Their application have led to the accumulation of more carbohydrates and other metabolites ultimately towards the plant tissues. The effect of such treatments on physico-chemical properties imparts favorable soil structure for root growth, which influenced the better growth as compared to chemical fertilizers. These results are in conformity with those of Ram et al. (2005). A synergistic interaction between sesame cake and biofertilizers like $A$. chroococcum and $A$. brasilense has resulted in enhanced production of growth promoting substances like gibberellic acid and indole acetic acid which has positive effect on physiological activity of plants thus enhanced fruit formation and total biomass of plants.

\section{Productivity traits}

The results presented in Table 2 clearly demonstrated that the plant contents of nitrogen, phosphate and potash, and the residual soil nitrogen, phosphate and potash contents were significantly increased by individual as well as combined inoculations as compared to untreated control. In the treatment of dual application of Azotobacter and Azospirillum together with $100 \%$ recommended dose of nitrogen recorded maximum plant nitrogen, phosphate and potash, and residual soil nitrogen, phosphate and potash contents. Increased nutrient contents in soil were due to more retention of nutrients which were added in the form of inorganic nitrogen, as well as the introduction of biofertilizers. Higher uptake of nutrients followed their increased supplements are natural and has been supported by many workers (Patil and Birader, 2002; Hari et al., 2007). The enhancement in yield at higher fertility level was possibly due to increased photosynthates associated with more vegetative growth as evident from differences in plant height and total biomass (Khurana et al., 2006). Gare et al. (2001) and Joseph et al. (2006) studied different yield attributing characters like chlorophyll content and ascorbic acid content improved following high nitrogen application. Long term application of organic manures

Table 2: Effect of sesame cake, bio-inoculants and N- fertilization on NPK contents in soil as well as in tomato plants in field condition*

\begin{tabular}{|c|c|c|c|c|c|c|c|}
\hline S. No. & Treatments & $\begin{array}{c}\text { Nitrogen } \\
\text { content } \\
\text { in plant } \\
(\mathrm{mg} / \mathrm{kg})\end{array}$ & $\begin{array}{l}\text { Phosphate } \\
\text { content in } \\
\text { plant } \\
(\mathrm{mg} / \mathrm{kg})\end{array}$ & $\begin{array}{l}\text { Potash } \\
\text { content } \\
\text { in plant } \\
(\mathrm{mg} / \mathrm{kg})\end{array}$ & $\begin{array}{c}\text { Soil } \\
\text { Nitrogen } \\
\text { content } \\
\text { (Kg/ha) }\end{array}$ & $\begin{array}{c}\text { Soil } \\
\text { Phosphate } \\
\text { content } \\
\text { (Kg/ha) }\end{array}$ & $\begin{array}{c}\text { Soil } \\
\text { Potash } \\
\text { content } \\
\text { (Kg/ha) }\end{array}$ \\
\hline$\overline{T 1}$ & $100 \%$ recommended $\mathrm{N}+$ Azotobacter + sesame cake & 85.06 & 80.13 & 73.82 & 205.40 & 76.94 & 93.44 \\
\hline T2 & $75 \%$ recommended $\mathrm{N}+$ Azotobacter + sesame cake & 82.72 & 76.29 & 70.54 & 199.37 & 73.96 & 90.92 \\
\hline T3 & $50 \%$ recommended $\mathrm{N}+$ Azotobacter + sesame cake & 79.54 & 73.63 & 68.16 & 193.84 & 70.65 & 88.72 \\
\hline T4 & $100 \%$ recommended $\mathrm{N}+$ Azospirillum + sesame cake & 93.26 & 89.77 & 84.36 & 223.60 & 86.34 & 103.36 \\
\hline T5 & $75 \%$ recommended $\mathrm{N}+$ Azospirillum + sesame cake & 90.94 & 86.20 & 80.72 & 217.65 & 83.22 & 99.65 \\
\hline T6 & $50 \%$ recommended $\mathrm{N}+$ Azospirillum + sesame cake & 88.16 & 82.74 & 77.68 & 211.50 & 80.17 & 96.48 \\
\hline T7 & $\begin{array}{l}100 \% \text { recommended } \mathrm{N}+\text { Azotobacter }+ \text { Azospirillum }+ \\
\text { sesame cake }\end{array}$ & 99.45 & 95.50 & 93.32 & 239.92 & 94.30 & 117.29 \\
\hline T8 & $\begin{array}{l}75 \% \text { recommended } \mathrm{N}+\text { Azotobacter }+ \text { Azospirillum }+ \\
\text { sesame cake }\end{array}$ & 96.38 & 93.44 & 90.69 & 233.54 & 91.42 & 112.45 \\
\hline T9 & $\begin{array}{l}50 \% \text { recommended } \mathrm{N}+\text { Azotobacter }+ \text { Azospirillum }+ \\
\text { Sesame cake }\end{array}$ & 95.56 & 91.26 & 87.23 & 227.48 & 88.63 & 107.84 \\
\hline T10 & Azotobacter + sesame cake & 69.59 & 63.94 & 55.40 & 175.09 & 58.28 & 77.40 \\
\hline T11 & Azospirillum + sesame cake & 73.62 & 67.05 & 59.60 & 183.70 & 63.49 & 80.74 \\
\hline T12 & Azotobacter + Azospirillum + sesame cake & 77.87 & 71.72 & 64.85 & 188.62 & 66.80 & 84.16 \\
\hline T13 & Azotobacter alone & 60.40 & 54.28 & 45.90 & 166.45 & 50.04 & 67.45 \\
\hline T14 & Azospirillum alone & 66.08 & 59.17 & 50.78 & 171.36 & 55.66 & 73.07 \\
\hline T15 & sesame cake alone & 56.86 & 50.39 & 40.63 & 159.82 & 46.81 & 64.30 \\
\hline T16 & $100 \%$ recommended NPK & 52.37 & 46.66 & 35.74 & 148.90 & 38.60 & 59.26 \\
\hline \multirow[t]{2}{*}{ T17 } & Untreated control & 35.84 & 31.70 & 18.63 & 116.22 & 27.55 & 50.37 \\
\hline & $\begin{array}{l}\text { C.D. }(P=0.05) \\
\text { C.D. }(P=0.01)\end{array}$ & $\begin{array}{l}5.82 \\
7.74\end{array}$ & $\begin{array}{l}4.99 \\
6.64\end{array}$ & $\begin{array}{l}3.67 \\
4.88\end{array}$ & $\begin{array}{l}12.35 \\
16.43\end{array}$ & $\begin{array}{l}3.77 \\
5.01\end{array}$ & $\begin{array}{l}6.24 \\
8.30\end{array}$ \\
\hline
\end{tabular}

*Each value is a mean of five replicates 
(Tiwari et al., 2002) and biofertilizers (Bhunia et al., 2006; Kumar et al., 2009) were reported to improve soil organic carbon and available $\mathrm{N}, \mathrm{P}, \mathrm{K}$ in soil by their sustaining soil health. Parham et al. (2002) reported that increased nutrient availability in organic matter with biofertilizers treatment may be due to increased hydrogenase and phosphatase activity, on the other hand, addition of organic manures promote the recycling of nutrients in the soil ecosystem which subsequently enhanced the level of soil enzymatic activity. Ours results are in conformity with those of Ramesh et al. (2006).

\section{Multiplication of nematodes population}

The multiplication of plant-parasitic nematodes was less in beds receiving the sesame cake and biofertilizers like Azotobacter and Azospirillum along with recommended doses of inorganic N fertilizer (50, 75 and 100\%), which revealed that the maximum reduction was observed with the treatment of sesame cake, biofertilizers together with 100\% recommended dose of inorganic nitrogen (Table 3). It may be due to release of phenols and nematostatic chemicals released from organic matters into amended soil. These compounds significantly decreased the nematodes population (Sitaramaiah and Singh 1978; Singh et al., 1983; Oka 2010). Organic wastes are commonly added to soil as a source of nutrients which improved the physical properties of soil. The decomposition of organic matter helps in modifying some physical, chemical and biotic contents of soil (Akhtar and Alam, 1993). The altered condition renders the soil atmosphere unfavorable for nematode activity. Biofertilizers are known to increase growth parameters and subsequently induced resistance against these pathogens as has been reported by Durrant and Dong (2004). The biofertilizers further improved the soil fertility through nitrogen fixation, thus supplemental nitrogen might be harmful against the population of plantparasitic nematodes. The available soil $\mathrm{N}$ was also found to increase in all the Integrated Pest Management as well as Integrated Nutrient Management systems. This increase may be attributed to higher microbial activity in the INM treatment which favoured the conversion of the organically bound $\mathrm{N}$ to inorganic form (Panwar et al., 2008). Similar enhancement of available $\mathrm{N}$ in such soil due to addition of organic matter was observed in rice (Singh et al., 2006). Phosphate is known to reduce soil $\mathrm{pH}$, which had an adverse effect on nematode multiplication (Pant et al., 1983). The higher P uptake in sesame cake may be attributed to its prolonged and consistent $\mathrm{P}$ availability due to its well decomposed nature. Higher P uptake by plants was also reported by Gupta and Mukhopadhyaya (1971). The increase in available K content in soil due to addition of organic manure might be attributed to the direct addition of $\mathrm{K}$ content into the available pool in soil. The results are in conformity with Laxminaryana and Patiram (2006).

\section{CONCLUSION}

Soil application of organic matter like sesame cake, biofertilizers such as Azotobacter and Azospirillum along with different

\section{Table 3: Effect of sesame cake, bioinoculants and $\mathrm{N}$-fertilization on the population of plant-parasitic nematodes infesting tomato plants in field condition*}

\begin{tabular}{|c|c|c|c|c|c|c|c|c|c|}
\hline \multirow[t]{2}{*}{ S. No. } & \multirow[t]{2}{*}{ Treatments } & \multicolumn{8}{|c|}{ Population of plant-parasitic nematodes per $200 \mathrm{~g}$ soil } \\
\hline & & Hop. & Hel. & Rot. & Trh. & Mel. & Dor. & Pra. & Total \\
\hline T1 & $100 \%$ recommended $\mathrm{N}+$ Azotobacter + sesame cake & 15 & 17 & 22 & 24 & 614 & 27 & 21 & 740 \\
\hline T2 & $75 \%$ recommended $\mathrm{N}+$ Azotobacter + sesame cake & 17 & 19 & 24 & 26 & 667 & 29 & 24 & 806 \\
\hline T3 & $50 \%$ recommended $\mathrm{N}+$ Azotobacter + sesame cake & 18 & 20 & 26 & 28 & 733 & 31 & 26 & 882 \\
\hline T4 & $100 \%$ recommended $\mathrm{N}+$ Azospirillum + sesame cake & 10 & 12 & 17 & 17 & 505 & 22 & 15 & 598 \\
\hline T5 & $75 \%$ recommended $\mathrm{N}+$ Azospirillum + sesame cake & 12 & 14 & 19 & 20 & 550 & 24 & 18 & 657 \\
\hline T6 & $50 \%$ recommended $\mathrm{N}+$ Azospirillum + sesame cake & 13 & 15 & 21 & 22 & 583 & 26 & 20 & 700 \\
\hline $\mathrm{T7}$ & $100 \%$ recommended $\mathrm{N}+$ Azotobacter + Azospirillum + sesame cake & 04 & 06 & 12 & 13 & 388 & 16 & 07 & 446 \\
\hline T8 & $75 \%$ recommended $\mathrm{N}+$ Azotobacter + Azospirillum + sesame cake & 06 & 08 & 14 & 15 & 425 & 19 & 10 & 497 \\
\hline T9 & $50 \%$ recommended $\mathrm{N}+$ Azotobacter + Azospirillum + sesame cake & 08 & 10 & 15 & 16 & 469 & 20 & 13 & 551 \\
\hline T10 & Azotobacter + sesame cake & 23 & 24 & 33 & 34 & 966 & 40 & 33 & 1153 \\
\hline T11 & Azospirillum + sesame cake & 22 & 23 & 31 & 32 & 874 & 37 & 30 & 1049 \\
\hline T12 & Azotobacter + Azospirillum + sesame cake & 20 & 21 & 28 & 29 & 782 & 34 & 28 & 942 \\
\hline T13 & Azotobacter alone & 26 & 27 & 40 & 38 & 1149 & 45 & 35 & 1360 \\
\hline T14 & Azospirillum alone & 24 & 25 & 36 & 35 & 1040 & 42 & 33 & 1235 \\
\hline T15 & sesame cake alone & 27 & 29 & 45 & 40 & 1267 & 50 & 37 & 1495 \\
\hline T16 & $100 \%$ recommended NPK & 33 & 37 & 58 & 54 & 1419 & 60 & 49 & 1710 \\
\hline T17 & Untreated control & 45 & 52 & 221 & 139 & 4468 & 135 & 107 & 5167 \\
\hline \multirow[t]{2}{*}{ T18 } & Initial population & 29 & 33 & 50 & 43 & 1592 & 53 & 37 & 1837 \\
\hline & $\begin{array}{l}\text { C.D. }(P=0.05) \\
\text { C.D. }(P=0.01)\end{array}$ & $\begin{array}{l}1.25 \\
1.66\end{array}$ & $\begin{array}{l}1.39 \\
1.85\end{array}$ & $\begin{array}{l}3.42 \\
4.54\end{array}$ & $\begin{array}{l}3.07 \\
4.08\end{array}$ & $\begin{array}{l}15.67 \\
20.81\end{array}$ & $\begin{array}{l}3.66 \\
4.86\end{array}$ & $\begin{array}{l}3.19 \\
4.24\end{array}$ & \\
\hline
\end{tabular}

*Each value is a mean of five replicates. Hop=Hoplolaimusindicus, Hel=Helicotylenchusindicus, Rot=Rotylenchulusreniformis, Trh=Tylenchorhynchusbrassicae, Mel=Meloidogyne incognita, Dor=Dorylaims, Pra=Pratylenchuscoffeae 
doses of nitrogen fertilizer has a significant effect on yield and agronomic parameters of tomato. To maintain sustainability in quality production through proper use of different nutrient sources will help to increase the fertility of soil. One such alternative is an integrated nutrient management that avoids depletion of soil organic matter and plant nutrients besides suppression of plant-parasitic nematodes. Recently, a great deal of attention has been paid to soil management practices that promote sustainable soil quality and crop productivity. The inference drawn from this study clearly explained that organic matters are not only the source of major nutrients but they also provide important micronutrients and plant-growth promoting molecules which together leads to good crop yield besides releasing nematostatic and fungicidal compounds. These are the important components of organic based agriculture system for the management of harmful organisms. For many farmers, the purchase of fertilizers and pesticides is constrained by their high costs and which are not affordable. Microbial inoculants comprising many kinds of naturally occurring beneficial organisms used in organic farming due to the demand of organically produced farm products. The utilization of such beneficial organisms with organic matters was found eco-friendly, bioefficaceous, economical, biodegradable and environmentally safe that could be ideal for the management of pathogenic organisms like parasitic nematodes. This low cost technology and alternative sources of nutrient supply have the potential to harvest reasonable yield of good quality.

\section{Author contributions}

S.A.T.: Main researcher, designing the experiment and wrote the article, SAFIUDDIN: collected and analyzed the data, R.R.: Provided the literature, M.I.: Research supervisor, Z.K.: Proof read and corrected the manuscript.

\section{REFERENCES}

Aguilar-Piedras J. J., M. L. Xiqui-Vasquez, S. Garcia-Garcia and B. E. Baca. 2008. Indole acetic acid production in Azospirillum. Revis. Lato. Microbiol. 50: 29-37.

Akhtar, M and M. M. Alam. 1993. Utilization of waste materials in nematodes control: A review. Bioresour. Technol. 45: 1-7.

AOAC 1980. Official Methods of Analysis. Association of analytical chemists. Iledn. Washington.

Bahadur, A., I. Singh, K. P. Singh, A. K. Upadhyay and M. Roy. 2009. Morpho-physiological, yield and quality traits in lettuce (Lactuca sativa) as influenced by use of organic manures and biofertilizers. Indian J. Agric. Sci. 79: 282-285.

Behl, R. K., S. Rupel, E. Kothe and N. Narula. 2007. Wheat $x$ Azotobacter $x$ VA Mycorrhiza interactions towards plant nutrition and growth: A review. J Appl Bot Food. Qual-Angewandte. Botanik. 81: 95-109.

Bhatti, D. S. and R. K. Jain. 1977. Estimation of loss in okra, tomato and brinjal due to Meloidogyne incognita. Indian. J. Nematol. 7: 37-41.

Bhunia, S. R., B. S. Chauhan, B. S. Yadav and A. S. Bhati. 2006. Effect of phosphorus irrigation and Rhizobium on productivity, water use and nutrient uptake in fenugreek (Trigonellafoenumgraecum). Indian. J. Agron.51: 239-241.

Brown, G. T. 1949. Pollen Slide Studies. In: C. C. Thomas, editor. Springer Field Illinois, USA.

Cavene-Adams, K., J. K. Campbell, S. Zaripheh, E. H. Jeffery and J. W. J. Erdman. 2005. The tomato as a functional food. J. Nutr. 135: $1226-1230$.

Chaitra, R. and V. S. Patil. 2007. Integrated nutrient management studies in China aster (Callistephu schinensis (L.) Nees). Karnataka. J. Agric. Sci. 20: 689-690.

Chitwood, D. J. 2003. Research on plant- parasitic nematode biology conducted by the United States department of agriculture agricultural research service. Pest. Manage. Sci. 59: 748-753.

Devidas, P., and L. A. Rehberger. 1992. The effect of exotoxin (Thurigiensin) form Bacillus thuringiensison Meloidogyne incognita and caenorhabdites elegans. Plant Soil. 145: 115-120.

Durrant, W. E and X. Dong. 2004. Systemic acquired resistance. Ann. Rev. Phytopathol. 42: 185-209.

Gare, B. N., S. M. More, M. G. Jadhav and A. V. Burli. 2001. Effect of spacing and fertilizers on yield of rainfed chilli in sub - montane zone of Maharashtra. J. Maharashtra. Agric. Univ. 25: 2700-271.

Govindan, K. and V. Thirumurugan. 2005. Synergistic association of Rhizobium with Phosphate solubilizing bacteria under different sources of nutrient supply on productivity and soil fertility in soybean (Glycine max). Indian J. Agron. 50: 214-217.

Govindan, M., K. M. Sreekumar and M. Subramanian. 2009. Response of ginger (Zingiber officinale) to Azospirillum inoculation at different levels of nitrogen application. Indian. J. Agric. Sci. 79: 821-823.

Gupta, D. C and M. C. Mukhopadhyay. 1971. Effect of N, P and K on root-knot nematode Meloidogyne javanica (Treub) Chitwood. Sci. Cult. 31: 246-247.

Hari, G. S., P. V. Rao and M. S. Reddy. 2007. Effect of nitrogen and potassium levels on yield and nutrient uptake in paprika (Capsicum annuum L.) under irrigated conditions of Northern Telangana zone Andhra Pradesh. Asian. J. Hort. 2: 193-196.

Hiscox, J. D. and G. F. Israelstam. 1979. A method for the extraction of chlorophyll from leaf tissue maceration. Can. J. Bot. 57: 1332-1334.

IITA. 1975. Selected methods for soils and plant analysis. International Institute for Troipical Agriculture, Ibadan.

Jackson, M. L. 1973. Soil Chemical Analysis. Prentice Hall of India Pvt. Lit. New Delhi.

Jain, N. K., N. L. Jat and G. R. Choudhary. 2007. Response of fennel (Foenicuculum vulgare) to inorganic nitrogen, farmyard manure and Azospirillum. Indian J. Agric. Sci. 77: 376-378.

Joseph, M., V. Veerabandran and M. Hemlatha. 2006. SPAD-502 and LCC values of wet seeded hybrid rice CORH 2 influenced by seed rate and nitrogen management. Int. J. Agric. Sci. 2: 385-388.

Kaur, C and H. C. Kapoor. 2008. Antioxidant activity in tomato: A function of genotype In: Preedy, V. R and R. R. Watson, editors. Tomatoes and Tomato Products Nutritional, Medicinal ant Therapeutic Properties. Science Publishers, USA.

Kavitha, K., K. S. Meenakumari and P. Sivaprasad. 2003. Effect of dual inoculation of native arbuscular mycorrhizal fungi and Azospirillumon suppression of damping off in chilli. Indian. Phytopathol. 56: 112-113.

Khurana, D. S., R. Singh, A. S. Sindhu and R. Singh. 2006. Effect of different levels of nitrogen in split doses on growth and yield of chilli. Indian J. Hort. 63: 467-469.

Knox, J., D. Jaggi and M. S. Paul. 2011. Population dynamics of Parthenium hysterophorous (Asteraceae) and its biological suppression through Cassia occidentalis (Caesalpiniaceae). Turk. J. Bot. 35: 111-119. 
Kumar, S., D. Singh and V. Nepalia. 2009. Performance of Fenugreek (Trigonella foenum-graecum) varieties at various fertilizer levels and bio fertilizer inoculations. Indian J. Agric. Res. 79: 80-83.

Laxminarayana, K. and Patiram. 2006. Effect of integrated use of inorganic, biological and organic manures on rice productivity and soil fertility in ultisols of Mezorum. J. Indian Soc. Soil. Sci. 54: 213-220.

Lindner, R. C. 1944. Rapid analytical methods for some of the more common inorganic constituents of plant tissues. Plant. Physiol. 19: $76-89$.

Malik, B. S., S. Paul, R. K. Sharma, A. P. Sethi and O. P. Verma. 2005. Effect of Azotobacter chroococcum on wheat (Triticum aestivum) yield and its attributing components. Indian J. Agric. Sci. 75: 600-602.

Mane, R, R. Sridevi, M. N. Salimath, S. K. Deshpande and A. B. Khot. 2010. Performance and stability of different tomato (Solarium Lycopersicum) genotypes. Indian J. Agric. Sci. 80: 898-901.

Mottaghian, A., H. Pirdashti, M. A. Bahmanyar and A. Abbasian. 2008. Leaf and seed micronutrient accumulation in soybean cultivars in response to integrated organic and inorganic fertilizers application. Pak. J. Biol. Sci. 11: 1227-1233.

Munakata, K. 1977. Insect feeding deterrents in plants. In: Shorey, H. H., J. J McKelvey Jr, editors. Chemical Control of Insect Behaviour, Wiley, New York, p. 93-102.

Oka, Y. 2010. Mechanism of nematode suppression by organic soil amendments: A review. Appl. Soil. Ecol. 44: 101-115.

Okon, Y and R. Itzigsohn. 1995. The development of Azospirillumas a commercial inoculant for improving crop yields. Biotechnol. Adv. 13: 415-425.

Olsen, S. R., C. V. Cole, F. S. Watanabe and L. A. Dean. 1954. Estimation of available phosphorus in soil by extraction with sodium carbonate. USDA Circular No. 939 Washington 19.

Pansey, V. G. and P. V. Sukhatme. 1978. Statistical Methods for Agricultural Workers. Indian Council of Agricultural Research (IARI), New Delhi.

Pant, V., S. Hakim and S. K. Saxena. 1983. Effect of different levels of $\mathrm{N}, \mathrm{P}, \mathrm{K}$ on the growth of tomato marglobe and on the morphometrics of root-knot nematode Meloidogyne incognita. Indian. J. Nematol. 13: 110-113.

Parham, J. A., S. P. Deng, W. R. Raun and G. V. Johnson. 2002. Long term cattle manure application in soil I. Effect on soil phosphorus levels, microbial biomass and dehydrogenase and phosphatase activities. Biol. Fertil. Soil. 35: 328-337.

Panwar, A. S. 2008. Effect of integrated nutrient management in Maize (Zea mays) - mustard (Brassica campestris var. Toria) cropping system in mid hills altitude. Indian J. Agric. Sci. 78(1): 27-31.

Patil, K. B. and D. P. Birader. 2002. Nutrient uptake of chilli as influenced by plant population and integrated nutrient levels in vertisols. J. Maharashtra Agric. Univ. 26: 337-339.

Pernes-Debuyser, A and D. Tessier. 2004. Soil physical properties as affected by long term fertilization. Eur. J. Soil Sci. 55: 505-512.

Pimentel, D. 1981. An overview of integrated pest management. Department of Ecology and Systematics. Mimeo, Cornell University, Ithaca, New York.

Rajaee, S., H. A. Alikham and F. Raiesi. 2007. Effect of plant growth promoting potentials of Azotobacter chroococcum native strains on growth, yield and uptake of nutrients in wheat. J. Sci. Technol. Agric. Nat. Resour. Water Soil Sci. 11: 285-297.

Ram, R. A., S. R. Bhriguvansi, N. Garg and R. K. Pathak. 2005. Studies on organic production of guava (Psidium guajava L.) Cv. 'Alahabad safeda'. First International Guava Symposium pp 6970, held during 5-8 December 2005 at CISH Lucknow.

Ramesh, P., M. Singh, N. R. Pawar, A. B. Singh and S. Ramana. 2006. Response of pigeonpea varieties to organic manures and their influence on fertility and enzyme activity of soil. Indian J. Agric. Sci. 76: 252-254.

Rana, R. K. and J. S. Chandel. 2003. Effect of bio fertilizers and nitrogen on growth, yield and quality of strawberry. Programs. Hortic. 35: 25-30.

Reddy, D. D. R. 1985. Analysis of crop losses in tomato due to Meloidogyne incognita. Indian. J. Nematol. 15: 55-59.

Sala, V. M. R., S. D. Freitas and A. P. D. Dasilveira. 2007. Interaction between arbuscular mycorrhizal fungi and diazotrophic bacteria in wheat plants. Pesqui. Agropecu. Bras. 42: 1593-1600.

Sarkar, S., S. R. Singh and R. P. Singh. 2003. The effect of organic and inorganic fertilizers on soil physical condition and the productivity of a rice wheat cropping sequence in Indian. J. Agric. Sci. 140: 419-425.

Sengupta S. K., Dwivedi Y. C and S. S. Kushwah 2002. Response of tomato (Lycopersicon esculentum Mill.) to bio inoculation at different levels of nitrogen. Veg. Sci. 29: 186-188.

Singh, A and J. N. Singh. 2006. Studies on influence of bio fertilizers and bio regulators on flowering, yield and fruit quality of strawberry Cv. Sweet Charlie. Ann. Agric. Res. 25: 261-264.

Singh, S., R. N. Singh, J. Prasad and B. P. Singh. 2006. Effect of integrated nutrient management on yield and uptake of nutrients by rice and soil fertility in rain fed upload. J. Indian Soc. Soil Sci. 54: 327-330.

Singh, S. P., V. M. Pant, A. M. Khan and S. K. Saxena. 1983. Attractiveness of Meloidogyne incognita larvae to roots of tomato and changes in biochemical content of plants as affected by oil-cakes and nematicides. Nematol. Medit. 11: 115-118.

Sitaramaiah, K and R. S. Singh. 1978. Effect of organic amendment on phenolic content of soil and plant response of Meloidogyne javanica and its host to related compounds. Plant Soil. 50: 671-679.

Southey, I. F. 1986. Laboratory Methods for Work with Plant and Soil Nematodes. Ministry of Agriculture. Fish and Food HMSO, London. p. 202.

Tiyagi, S. A., I. Mahmood and R. Rizvi. 2010. Studies on management of root-knot and reniform nematodes infesting tomato and chilli. Environ. Biol. Conserv. 15: 16-21.

Tiwari, A., A. K. Dwivedi and P. R. Dikshit. 2002. Long term influence on organic and inorganic fertilization on soil fertility and productivity of soybean-wheat system in a Vertisol. J. Indian Soc. Soil Sci. 50: 472-475.

Upadhyay, A. K., A. Bahadur and J. Singh 2012. Effect of organic manures and bio fertilizers on yield, dry matter partitioning and quality traits of cabbage (Brassica oleracea var. Capitata). Indian J. Agric. Sci. 82: 31-34.

Verma, 0. P., S. Paul and M. S. Rathi. 2000. Synergistic effect of co inoculation of Azotobacter chroococcum and Rhizobium on pea (Pisum sativum). Ann. Agric. Res. 21: 418-420.

Wange, S. S. and R. H. Kale. 2003. Response of okra and bitter guard to diazotrophsv and graded level of nitrogen. J. Soils Crops. 13: 271-274.

Widham, G. L., M. T. Widliam and W. P. William. 1989. Effects of Trichoderama species on maize growth and Meloidogyne arenaria reproduction. Plant Dis. 73: 493-494.

Wu, S. C., Z. H. Cao, Z. G. Li, K. C. Cheung and M. H. Wong. 2005 Effects of bio fertilizer containing $\mathrm{N}$-fixer, $\mathrm{P}$ and Solubilizers and AM fungi on maize growth: A greenhouse trial. Geoderma, 125: 155-166.

Yadav, D. S and A. Kumar. 2009. Long term effects of nutrient management on soil health and productivity in rice (Oryza sativa) wheat (Triticum aestivum) system. Indian J. Agron. 54: 15-23.

Yang, C., L. Yang, Y. Yang and Z. Quyang. 2004. Rice root growth and nutrient uptake as influenced by organic manure in continuously and alternatively flooded paddy soil. Agric. Water Manage. 70: 67-81. 